\title{
KEBIJAKAN PENANGANAN COVID-19 DARI PERSPEKTIF HUKUM PROFETIK
}

\section{COVID-19 HANDLING POLICY OF PROFETICAL LAW PERSPECTIVE}

\author{
Supriyadi $^{1}$ \\ ${ }^{1}$ Fakultas Hukum Universitas Tadulako Palu \\ Jl. Soekarno-Hatta KM.9, Tondo, Mantikulore, Kota Palu, Sulawesi Tengah \\ E-mail: adipandean37@gmail.com
}

\begin{abstract}
This research will look at the policy of handling Covid-19 by the government from the viewpoint of prophetic law based on three main pillars namely humanization, liberation and transcendence. In this study the authors use normative research using the regulatory approach, the prophetic legal concept approach and the case approach. The results of the study showed that the Covid-19 handling policy carried out by the government still contained inaccurate recipient data, distribution of basic needs assistance that was not carried out in stages from the Central Government to the Regional Government but carried out simultaneously, there was a legal basis that opened space abuse of authority due to impunity for officials.
\end{abstract}

Keywords: Policy, covid-19 management, prophetic law

\section{Intisari}

Penelitian ini akan melihat kebijakan penanganan Covid-19 oleh pemerintah dari sudut pandang hukum profetik dengan berbasis pada tiga pilar utama yakni humanisasi, liberasi dan transenden. Dalam penelitian ini penulis mengunakan penelitian normatif dengan mengunakan pendekatan peraturan perundang undangan, pendekatan konsep hukum profetik dan pendekatan kasus. Adapun hasil penelitian menunjukan bahwa kebijakan penanganan Covid-19 yang dilakukan oleh pemerintah masih terdapat data penerima bantuan yang tidak akura, penyaluran bantuan kebutuhan dasar yang tidak dilakukan secara bertahap dari Pemerintah Pusat sampai kepada Pemerintah Daerah melainkan dilakukan secara bersamaan, terdapat landasan hukum yang membuka ruang penyalagunaan wewenang karena adanya kekebalan hukum bagi pejabat.

Kata Kunci: Kebijakan, penagananan covid-19, hukum profetik

\section{PENDAHULUAN}

Saat ini negara - negara di belahan dunia termasuk Indonesia tengah konsen menangani penyebaran pandemik virus corona (Covid-19), berbagai langkah dan tindakan telah dilakukan mulai dari penerapan Social distancing, physical distancing sampai dengan pembatasan sosial berskala besar (PSBB). Kesemuanya ditempu oleh pemerintah dengan satu tujuan untuk menekan angka penyebaran dan menghilangkan virus dari Indonesia. Langkah kongret yang 
diambil oleh pemerintah dari aspek hukum ialah dengan mengeluarkan Peraturan Pemerintah Pengganti Undang - Undang Nomor 1 Tahun 2020 tentang Kebijakan Keuangan Negara Dan Stabilitas Sistem Keuangan Untuk Penanganan Pandemi Corona Virus Disease 2019 (Covid-19) Dan/Atau Dalam Rangka Menghadapi Ancaman Yang Membahayakan Perekonomian Nasional Dan/Atau Stabilitas Sistem Keuangan (Perpu No 1 Tahun 2020). Kehadiran Perpu No 1 Tahun 2020 sebagai langkah hukum untuk memberikan kepastian hukum ditengah ketidakpastian yang selama ini terjadi dalam hal penanganan Covid-19 bagi pemerintah dan pemerintah daerah.

Kedudukan Indonesia sebagai negara hukum (Pasal 1 ayat (3) UUD Negara Republik Indonesia Tahun 1945) mengamanatkan bahwa semua kebijakan dan tindakan yang diambil dalam hal apapun (termasuk penanganan covid-19) haruslah berlandaskan hukum sebagai legalitas dalam bertindak. Prinsip negara hukum yakni berdiri diatas ketentuan hukum sebagai sebuah isntrumen dalam bertindak yang legal, Aristoteles menyebutkan negara yang berdiri diatas hukum yang menjamin keadilan kepada warga negaranya. Keadilan menurutnya merupakan syarat bagi tercapainya kebahagiaan hidup untuk warga bagi suatu negara. Bagi Aristoteles, yang memerintah dalam negara bukanlah manusia sebenarnya, melainkan pikiran yang adil, sedangkan penguasa sebenarnya hanya pemegang hukum dan keseimbangan saja. ${ }^{1}$ Sedangkan menurut Maria Farida, prinsip negara hukum Indonesia adalah negara hukum pengurus (Verzonginstaat). ${ }^{2}$ Dalam rangka mewujudkan tujuan negara tersebut, pemerintah dituntut untuk melakukan berbagai macam fungsi dan tugas, yang pada umumnya terdiri dari tugas mengatur dan tugas mengurus, yang muaranya adalah perwujudan kemaslahatan bagi setiap warga negara. Senadah dengan hal tersebut, Arief Sidharta menyatakan negara hukum menjamin kepastian hukum terwujud dalam masyarakat dan prediktibilitasnya sangat tinggi. Sehingga dinamika kehidupan bersama dalam masyarakat bersifat "predictable" atau dapat diramalkan. ${ }^{3}$

Sebagai wujud legalitas bertindak dalam penanganan wabah pandemi, lahirnya Perpu No 1 Tahun 2020, sebelum keluarnya Perpu No 1 Tahun 2020 yang spesifik mengatur subtansi keuangan penanganan pandemi, Undang Undang Nomor 6 Tahun 2018 tentang Kekarantinaan Kesehatan (UU Karantina Kesehatan) telah memberikan legalitas bagi pemerintah dalam mengambil langkah yang tepat ditengah penyebaran virus corona demi kemaslahatan masyarakat Indonesia.

Kebijakan pemerintah dalam penanganan Covid-19 dapat dilihat dari beberapa aspek, baik dari aspek sosial, budaya, politik, ekonomi dan tak terkecuali dari aspek hukum. cara pandang melalui hukum tentu tidak terlepas dari corak dan

\footnotetext{
${ }^{1}$ Moh. Kusnardi dan Harmaily Ibrahim, 1998, Pengantar Hukum Tata Negara Indonesia, PS HTN FH UI dan Sinar Bakti, hlm. 153

2 Maria Farida Indrati Soeprapto, 1998, Ilmu Perundang-undangan (Dasar-Dasar dan Pembentukannya), Jakarta, Kanisius, hlm. 1

3 Sidharta, Arief , 2004, "Kajian Kefilsafatan tentang Negara Hukum”, dalam Jentera (Jurnal Hukum), "Rule of Law", Pusat Studi Hukum dan Kebijakan (PSHK), edisi 3 Tahun II, November, Jakarta hlm.124-125
} 
warna konsep hukum itu sendiri, corak hukum klasik misalnya memandang bahwa tindakan dan kebijakan negara dalam situasi pandemi memainkan peran sebagai negara menjaga keamanan dan ketertiban semata, konsep ini sangat familiar dibenak kita denga sebutan negara jaga malam yang dikembangkang oleh seorang pemikir bernama Immanuel Kant. Nampaknya aktifitas yang bercirikan konsep klasik ini terlihat mulai menampakan diri dari tabir persembunyiannya selama ini. Pemerintah melalui organ negaranya (Polisi dan TNI) dijadikan alat oleh negara untuk memutus aktifitas masyarakat pada saat pandemi, kebijakan dan tindakan tersebut menimbulkan tanya mengenai status negara kita saat ini.

Pada tanggal 31 Maret 2020 pemerintah (Presiden) mengumumkan status darurat kesehatan ${ }^{4}$, kemudian pada tanggal 13 April 2020 ditetapkan kembali status penyebaran Covid-19 sebagai bencana nasional ${ }^{5}$. Kedua penetapan status diiatas, sungguh makin membuat kebingungan masyarakat karena tidak memberikan kepastian hukum akan status penyebaran pandemi di Indonesia. Konsep darurat kesehatan jauh berbeda dengan konsep Bencana Nasional serta keduanya tunduk pada ketentuan undang - undang yang berbeda. Hal ini memberikan kekacauan terhadap lembaga mana yang akan menjadi leading sektor dalam penanganan Covid-19.

Disamping persoalan dualisme status hukum yang ditetapkan oleh pemerintah terhadap Covid-19 serta terdapat disharmonisasi prodak hukum yang berlaku, hal yang patut juga menjadi perhatian ialah mengenai kekacauan data penerima bantuan sosial bagi masyarakat yang terdampak secara langsung maupun tidak langsung oleh penyebaran pandemi. Kekacauan data terhadap penerimaan bantuan sosial diakui oleh menteri keuangan republik Indonesia, Sri Mulyani Indrawati yang menyatakan adanya kemungkinan tumpang tindih data dalam penyaluran bantuan sosial atau bansos selama masa pandemi virus Corona atau Covid-19 karena data terpadu Kementerian Sosial belum dimutakhirkan dengan kondisi setelah adanya Covid-19. Dengan data yang tidak termuktahirkan mengakibatkan banyak masyarakat yang tidak mampu justru tidak mendapatkan bantuan dari pemerintah. Salah satu kasus pertama yang mencuat ke publik ada di Bekasi. Saat itu, publik dihebohkan dengan kabar pemilik dua mobil menerima bansos. Sementara $20 \mathrm{KK}$ yang berhak di RT 04/RW 09 Kelurahan Telukpucung, Bekasi Utara justru tak mendapat bantuan sama sekali. ${ }^{6}$

Dari kacamata hukum profetik yang berlandaskan pada tiga pilar utama yakni humanisasi, liberasi dan transendental, suatu kebijakan hukum haruslah memberikan maslahah bagi setiap warga negara terlebih lagi dalam keadaan seperti saat ini. Kebijakan pemimpin terhadap rakyatnya harus berdasarkan pada kemaslahatan (tasharraf al imam 'ala raiyyah manuuthun bi al mashlahah). Hal ini sejalan pula dengan tujuan berhukum dalam Islam, yang salah satu tujuan

\footnotetext{
${ }^{4}$ https://republika.co.id/berita/q81 xp0440/darurat-kesehatan-bukan-darurat-sipil-ini-pidatopresiden. Diakses 14 Juni 2020

${ }^{5}$ https://setkab.go.id/presiden-tetapkan-bencana-nonalam-penyebaran-covid-19-sebagaibencana-nasional. Diakses 14 Juni 2020

${ }^{6} \mathrm{https}: / /$ www.cnnindonesia.com/nasional/20200512093741-32-502340/semrawut-databansos-corona-saling-serang-pusat-daerah. Diakses tanggal 14 Juni 2020
} 
berhukum dalam Islam (maqashid al syariat) adalah hifz al nafs yaitu setiap pelaksanaan hukum harus memelihara kelangsungan hidup manusia, karena itu tidak dibenarkan upaya-upaya kehidupan yang berakibat hilangnya keberadaan manusia. $^{7}$

Keberlangsungan hidup masyarakat di bumi pertiwi merupakan kemaslahatan serta hukum yang tertinggi. Dalam pandangan al-Gazali maslahah memiliki lima prinsip dasar yakni memelihara agama, jiwa, akal budi, keturunan dan harta kekayaan. Lima prinsip dasar (al-usul al-khamsah) oleh al-Gazali ditempatkan pada posisi kekuatan maslahah daruriyyat, pemeliharaan terhadap kelima prinsip tersebut merupakan level terkuat dan tertinggi dari maslahah. Sebaliknya kebijakan atau tindakan yang merusak kelima hal tersbut dinilai sebagai mafsadah (kerusakan atau akibat buruk bagi kelompok) ${ }^{8}$. Lebih lanjut, pondasi berfikir hukum profetik dalam melihat fenomena atau fakta emipirik sebuah peristiwa, keadaan maupun perbuatan hukum berbasis pada tidak konsep dasar yakni humanisasi, liberasi dan transendensi ${ }^{9}$. Ketiga pilar tersebut berjalan dan tampil secara berurutan, humanisasi merupakan landasan ontologis, kemudian liberasi adalah landasan epistemologis, dan transendensi sebagai landasan aksiologis. Oleh karena transendensi dipandang sebagai nilai yang dituju, maka keberadaan manusia dan kehidupan mereka diabdikan kepada tujuan-tujuan transendensi itu. ${ }^{10}$

Inti dari humanisasi yang berada pada landasan ontologis ialah memanusiakan manusia, dalam pandangan hukum profetik setiap kebijakan dan tindakan yang diambil oleh pemimpin sebagai wakil tuhan (konsep kedaulatan Tuhan) harus memanusiakan manusia. Kemudian liberasi yang berada pada landasan epistemologis yang memiliki makna kesetaraan setiap warga negara dalam pengambilan kebijakan dan tindakan pemerintahan yang oleh paham positivisme disebut sebagai kesamaan kedudukan didepan hukum dan pemerintahan. Yang terakhir ialah sesuai nilai yang ideal yang dituju, artinya kebijakan dan tindakan pemerintah harus didasarkan akan nilai - nilai ketuhanan.

Kaitannya dengan kebijakan dan tindakan yang diambil oleh pemerintah dalam penanganan pendemi Covid-19, menjadi pertanyaan yang sangat menarik untuk dibahas lebih lanjut, sudahkan kebijakan yang diambil telah memanusiakan manusia (prespektif humanisasi), sudahkah bernilai kepastian, keadilan dan kemanfaatan (prespektif liberasi) dan sudahkah didasarkan atas nilai - nilai ketuhanan sebagai nilai yang dituju (prespektif transenden). Berangkat prolemtaika yang tergambarkan diatas, maka penulis merumuskan masalah: Pertama, Apakah pemenuhan kebutuhan dasar bagai masyarakat telah berlandaskan prinsip humanisasi?. Kedua, Apakah landasan hukum penanganan

${ }^{7}$ Supriyadi dan Ivan Yudharta, "Maslahah Dibalik Penundaan Pilkada: Pemikiran yang dilandaskan pada kajian Hukum Profetik", Mercusuar, 31 Maret 2020. Lihat Juga Supriyadi, "Maslahah dibalik Penundaan Pilkada", Kareba Sulteng. 4 April 2020.

${ }^{8}$ Ibid.

${ }^{9}$ Kuntowijoyo, 1998, Paradigma Islam: Interpretasi untuk Aksi, Cet.VIII, AE. Priyono (ed), Bandung: Mizan, hlm. 289. Lihat juga : Absori et al, Pemikiran Hukum Profetik Ragam Paradigma Menuju Hukum Berketuhanan, Yogyakarta ; Ruas Media, 2018, hlm. 25.

$10 \quad$ Shidarta, https://business-law.binus.ac.id/2019/05/02/ antara_humanisasi_liberasi_transendensi/. Diakses pada tanggal 1 Mei 2020 
Covid-19 telah berlandaskan prinsip Liberasi?. Ketiga, Apakah kebijakan penaganan Covid-19 telah sejalan dengan prinsip Transenden?

\section{METODE PENELITIAN}

Penelitian ini merupakan penelitian hukum normatif atau juga dikenal dengan penelitian doktrinal. Dalam penelitian ini juga digunakan beberapa pendekatan, di antaranya pendekatan perundang-undangan (statuta approach), pendekatan konseptual (conseptual approach), dan pendekatan kasus (case statutory $)^{11}$. Pendekatan perundang-undangan dilakukan dengan menelaah peraturan perundang-undangan yang mengatur tentang penanganan covid-19. Pendekatan konseptual yang digunakan ialah pendekatan hukum profetik dengan berbasis pada pilar humanisasi, liberasi dan transenden. Sedangkan pendekatan kasus dilakukan untuk fenomena kebijakan penanganan covid-19. Sumber Bahan hukum terdiri dari bahan hukum primer, bahan hukum sekunder dan bahan hukum tersier.

\section{HASIL DAN PEMBAHASAN}

\section{Paradigma hukum Profetik: Nilai Humanisme, Liberasi dan Transendental}

Bagi penstudi hukum di Indonesia, konsep hukum profetik mungkin masih sangat asing menjadi bahan diskusi terlebih sebagai rujukan dalam penulisan karya ilmiah (Tesis bahkan disertasi). Konsep hukum profetik lahir pada erapostmoderenisasi dan cukup terbilang baru dalam perkembangannya di Indonesia. Konsep berfikir ini awalnya dikembangkan di Universitas Islam Indonesia dan Universitas Muhammadiyah Surakarta. sejak kelahiranya sampai dengan saat ini perkembangan paradigma hukum profetik menunjukan tren yang cukup positif, telah banyak penstudi hukum yang melihat fenomena empirikal dengan menggunakan sudut pandang kajian hukum profetik. Sebagai ilmu pengetahuan yang didasarkan atas nubuwwah kenabian menjadi faktor utama pemirikan hukum ini berkembang begitu pesat dan diterima dalam pergaulan ilmu hukum nasional. Seperti kita ketahui bersama, corak berhukum kita di Indonesia sangat dipengaruhi oleh paham positivisme, yang mendudukan hukum positif sebagai panglima utama dalam menyelesaikan prolematika sosial. Namun, jika kita melihat kelahiran faham positivisme hukum secara keras memisahkan anasiranasir non hukum (moral) masuk dalam bagian hukum itu sendiri. Padangan ini bisa kita melihat dari pikiran yang dikembangkan oleh hans kelsen dengan konsep pure of law, yang mana hukum didudukkan terpisah dari anasir moral sekalipun. Dalam perkembangannya cara membentuk hukum dalam konteks Indonesia tidak menutup diri terhadap masuknya anasir moral dalam hukum, konsep moral yang masuk dalam tubuh hukum positif tersebut masih berada jauh dari keadilan yang berdimensi humanisasi dalam kerang pikir hukum profetik.

Paradigma profetik atau juga sering disebut dengan istilah Ilmu Sosial profetik merupakan proses pengilmuan ayat-ayat al-Quran. Paradigma prophetisme menggambarkan sebuah proses integrasi keilmuan (religious science

${ }^{11}$ Peter Mahmud Marzuki, 2005, Penelitian Hukum : Edisi Revisi. Jakarta : Kencana, hlm. 133 
dan non religious science) yang sejatinya telah ada dalam perkembangan keilmuan Islam. Oleh karena itu, paradigma profetik dapat dijadikan alternatif paradigma baru di dalam era pos-modern, yang memiliki kareateristik dedifferensiasi. Lahirnya Ilmu Sosial Profetik, terinspirasi dari dua tokoh besar, yaitu Muhammad Iqbal dan Roger Garaudy, seorang filosof dari Prancis. Kunto Wijoyo memaknai transendental dengan mendasarkan keimanan kepada Allah dengan mengenalkan ilmu profetik berupa humanisasi (ta'muruna bil ma;ruf), liberasi (tanhauna anil munkar) dan transendensi (tu'minuna billah).

Padadasarnya, Ilmu Hukum Profetik berawal dari Ilmu Sosial Profetik yang digagas oleh Kuntowijoyo. Ilmu Sosial Profetik bermaksud tidak sekedar mengubah demi perubahan, namun mengubah berdasarkan suatu cita cita profetik. Cita-cita ini terkandung dalam Qs Ali Imran : 104, kemudian diderivasi menjadi humanisasi, liberasi dan transendensi, yang menjadi unsur dari Ilmu Sosial Profetik itu sendiri. ${ }^{12}$

Dalam Kamus Besar Bahasa Indonesia(KBBI), kata "profetik" mengandung arti sebagai kata sifat berkenaan dengan kenabian atau ramalan. Kata "ramalan" di dalam terminologi ilmu hukum, tampaknya mendekati kata preskripsi, yaitu semacam resep dokter untuk mengatasi suatu penyakit. ${ }^{13}$ Pemaknaaan profetik berawal dari bahasa inggris prophet (nabi) sedangkan prophetic bermakna (kenabian). Yaitu sifat nabi yang mempunyai ciri sebagai manusia yang ideal secara spiritual-individual, tetapi juga menjadi pelopor perubahan, membimbing masyarakat ke arah perbaikan dan melakukan perjuangan tanpa henti melawan penindasan. ${ }^{14}$

Hukum profetik merupakan hukum yang beresensi nilai Ilahiyah yang dibawa oleh para nabi. Dengan demikian, paradigma hukum profetik tidak lepas dari risalah kenabian yang memberikan pedoman hukum kehidupan, pencarian kebenaran hakiki dan prinsip-prinsip keadilan. ${ }^{15}$ Hukum profetik sebagai hukum yang bersifat kenabian secara ontologis berada dalam ranah Tauhid yang dibawa oleh para nabi yang kebenarannya telah teruji dalam perjalanan sejarah perubahan sosial dan perkembangan hukum. Secara aksiologis hukum profetik beresensi nilai kebenaran hakiki yang berbeda dengan hukum atheis dan sekuler. Dalam perspektif epistemologis, pencarian kebenaran yang dilakukan oleh hukum profetik tidak lepas dari dimensi aqidah, keimanan dan rokhaniah. Sehingga berbeda dengan hukum sekuler dan atheis yang mengandalkan kepada potensi akal semata. ${ }^{16}$

Hukum profetik merupakan hukum yang bersukma keadilan serta melindungi martabat kemanusiaan dengan berdimensi transendental dan memiliki tali sumbu nilai dengan kebenaran hakiki dan terkait dengan struktur rokhanih masyarakat beradab. Sebagai konstitusi kehidupan umat manusia yang

\footnotetext{
${ }^{12}$ Absori dkk, 2015, Paradigma Hukum Profetik; kritik terhadap asumsi asumsi dasar Ilmu Hukum Non-Sistematik, Jogja: Genta Publishing, hlm 288.

${ }^{13}$ Shidarta. Op.Cit.

${ }^{14}$ Nur Hanafi, “Konseptualisasi Profetik”, Jurnal al Hikmah, 5(1), 1-8, hlm. 2

${ }^{15}$ Artidjo Alkostar, "Peluang dan Tantangan Hukum Profetik Bagi Pengembangan Hukum Nasional Di Era Digital”, Makalah tidak dipublikasikan, tanpa tahun, hlm 1.

${ }^{16}$ Ibid.
} 
substansinya bersumber nilai Ilahiyah, hukum profetik diperuntukkan bagi bangsa manusia yang memberikan tranformasi nilai kebajikan.

"Kamu adalah umat terbaik yang dilahirkan untuk manusia, menyuruh kepada yang makruf, dan mencegah dari yang mungkar, dan beriman kepada Allah" (QS. Ali-Imran: 110).

Kutipan ayat di atas merupakan pemantik lahirnya landasan trilogi profetik yaitu humanisasi, liberasi, dan transendensi. ${ }^{17}$ Ilmu hukum profetik sengaja dihadirkan dan disajikan serta diwacanakan sebagai menu sajian tentang gagasan keilmuan di tengah-tengah jagat para pecinta ilmu, khususnya ilmu hukum di era postmodern ini. Ini dimaksud sebagai upaya pencarian dan penemuan kebenaran nilai-nilai hukum (humanisasi/amar ma'ruf), pembebasan (liberasi/nahi munkar) dari cara berhukum yang materialis-sekula, jauh dari nilai-nilai ketuhanan (transendensi) yang terjadi di zaman modern, yang terbukti telah merendahkan peradapan manusia (dehumanisasi).

Sebenarnya konsep berfikir yang bermatra profetik ini telah ada dalam sejarah ketetanegaraan Indonesia. Jika mencoba sedikit kembali pada sejarah itu, disana akan diitemukan semangat yang berdimensi paradigma profetik dalam pembahasan yang kemudian melahirkan Pancasila dan UUD Tahun 1945 (sebelum amandemen). Tanpa mencoba bermaksud untuk mengulang dan menjelaskan kembali terkait perubahan frasa sila pertama dalam Pancasila yang tadinya bernafas sangat "islami" berubah menjadi nafas "ketuhanan" sudah menunjukan ciri objektivikasi transendental dan empirikal dalam prespektif profetik. frasa awal rumusan pancasila bermakna transendental yakni sesuatu yang ingin dicapai yang berada tingkat nilai ideal, akan tetapi untuk mencapai nilai transendental juga harus berjalan seirama dengan nilai liberasi dan humanisasi (fakta empirikal). Olehnya itu, konsep frasa pertama berubah dalam rumusan pancasilan ialah sebagai wujud objektivikasi yang seirama dari tiga pilar dalam hukum profetik.

Dalam pembentukan norma Hukum, Objektivikasi tetap menganggap wahyu sebagai sumber hukum. Namun dia harus disepakati terdahulu menjadi sumber hukum negara, yaitu hukum positif. Dengan demikian, syariat islam tidak langsung menjadi hukum negara, namun terlebih dahulu melalui proses objektivikasi. ${ }^{18}$ Kunto kemudian menderivasikan kelima Sila menjadi, pertama Pluralisme Postif, kedua, kebebasan yang beradab, ketiga, demokrasi budaya, keempat, negara objektif, dan kelima, nasionalisme sosiologis. Dari Pluralisme Positif, kebebasan yang beradab, dan demokrasi budaya lahirlah keadilan hukum yang bersifat intersubjektif. Hukum dirumuskan dan berlaku kepada masing masing kelompok. ${ }^{19}$

17 Bobby Briando, Agung Sulistyo Purnomo, 2019, "Etika Profetik Bagi Pengelola Keuangan Negara, Jurnal Akuntansi Multiparadigma, Volume 10, Nomor 2, Agustus, hlm. 342

${ }^{18}$ Kuntowijoyo, 1997, Identitas Politik Umat Islam, Bandung: Mizan, hlm 69.

${ }^{19}$ Ibid, hlm. 319. 


\section{Pemenuhan Kebutuhan Dasar Bagi Masyarakat: Telah Prespektif Humanisasi}

Pada subbab sebelumnya kita telah diantar untuk mengenali konsep paradigma hukum profetik dan dinamika kebijakan penanganan covid-19 yang dilakukan oleh Pemerintah. Dalam subbag ini akn dielaborasi sudut pandang hukum profetik dalam melihat kebijakan yang diambil oleh pemerintah terhadap penanganan covid-19. Sebagaiman telah diuraikan diatas bahwa dasar pikiran hukukm profetik berada pada tiga dasar utama yanki humanisasi, liberasi dan transendensi. Ketiga dasar tersebut atau beberapa pakar hukum profetik juga menyebutnya sebagai pilar hukum profetik dijadikan alat untuk menilai kebijakan penanganan virus corona.

Dasar utama yakni humanisasi, humanisasi bermakna memanusiakan manusia. Manusia sebagai makhluk yang diciptakan oleh Allah (tuhan yang maha esa) pada prinsipnya memiliki nilai ideal dan nilai empirikal, nilai ideal yang berada pada diri manusia bersemayam dalam hati dan pikirannya, tindakan yang dilakukan yang didasari atas hati dan pikiran selalu berujung pada keadilan dan kemaslahatan bagi setiap makhluk hidup termasuk manusia. Sedangkan nilai empirikal berada dan bersemayam pada nafsu manusia, berbeda dengan tindakan yang didasarkan atas nilai ideal, tindakan yang didasarkan atas nilai empirikal (nafsu) kerapkali menghadirkan ketidakadilan dan mafsadah (kerusakan) bagi mahkluk termasuk juga manusia itu sendiri. ${ }^{20}$ Dalam konteks kenegaraan (Indonesia) catatan dan penegasan nilai hukum profetik yang memerintahkan setiap manusia dalam rumah bernama Indonesia untuk saling memanusiakan satu dengan lainnya ialah termaktub dalam sila ke 2 Pancasila "Kemanusiaan Yang Adil dan Beradab". Sepirit dan pesan nilai yang terkandung dalam sila ke 2 Pancasila merupakan spirit yang bernafaskan pilar humanisasi, sepirit tersebut mejadi pedoman untuk dijawentahkan dalam bentuk kongkret (hukum positif) untuk memanusiakan manusia.

Sebagaiamana telah diurai pada subbab sebelumnya (tanpa maksud untuk mengulang) kehadiran beberapa kebijakan baik dari apek himbauan maupun hukum nampaknya tidak sejalan dengan konsep humanisasi. Ketidaksejalanan itu tentu kita bisa lihat dan analisis dari fakta - fakta kongret yang ada dipergaulan interaksi hukum masyarakat (untuk menganti kata pergaulan sosial). Misalnya kebijakan pemberlakuan social distancing, physical distancing dan saat ini banyak yang bermohon unutk PSBB, pemberlakukan kebijakan ini pada prinsipnya sangat baik untuk memutus matarantai penyebaran covid-19 namun menjadi tidak humanisasi karena tidak diikuti dengan kebijakan untuk penyediaan sumber hidup dan penghidupan masyarakat selama masa pelaksaanaan kebijakan. Tentu kita telah sama - sama mengetahui atau bahkan ada sebagian dari kita yang merasakan langsung dampak terhadap terbatasnya ruang gerak didalam mencari sumber hidup dan penghidupan.

Dalam ketentuan Pasal 8 UU Karantina Kesehatan menyebutkan "Setiap Orang mempunyai hak mendapatkan pelayanan kesehatan dasar sesuai

${ }^{20}$ Mohammad Rusfi, 2014, "Validitas Maslahat Al-Mursalah Sebagai Sumber Hukum". $A L$ - 'ADALAH Vol. XII, No. 1 Juni, hlm. 65. 
kebutuhan medis, kebutuhan pangan, dan kebutuhan kehidupan sehari-hari lainnya selama Karantina”. Kemudian sejalan dengan ketentuan Pasal 8 UU Karantina Kesehatan, didalam ketentuan Pasal 4 ayat (3) Perpu No 21 Tahun 2020 tentang PSBB menegaskan "Pembatasan kegiatan sebagaimana dimaksud pada ayat (1) huruf $c$ dilakukan dengan memperhatikan pemenuhan kebutuhan dasar penduduk". Lebih lanjut penjelasan Pasal 4 ayat (3) menjelaskan yang dimaksud dengan "kebutuhan dasar penduduk" meliputi kebutuhan pelayanan kesehatan, kebutuhan pangan, dan kebutuhan kehidupan sehari-hari lainnya. Kedua ketentuan Pasal tersebut meskipun diatur dalam dua prodak hukum yang berbeda akan tetapi memiliki substansi pengaturan dan spirit yang sama yakni mengamanatkan pemerintah wajib menyediakan kebutuhan dasar bagi masyarakat ditengah pemberlakukan kebijakan penanganan Covid-19.

Bantuan terhadap kebutuhan dasar bagi masyarakat dari pemerintah ditengah wabah covid-19 seperti saat sekarang ini dapat menjadi penyambung hidup jutaan orang yang terkena dampak penyebaran virus corona. Sayangnya, fakta empirik menunjukan keadaan yang jauh berbeda dari desain norma yang disebutkan diatas, pengelolaan data yang buruk selama bertahun-tahun membuat program jaring pengaman sosial yang diluncurkan Presiden Joko Widodo compang-camping di lapangan. Centang-perenangnya kebijakan pemerintah tentang bantuan sosial bagi korban bencana kesehatan ini mungkin paling tecermin dari gugatan Bupati Bolaang Mongondow Timur Sehan Salim Landjar. Video Sehan yang meradang karena tumpang-tindihnya penyaluran bantuan akibat pandemi Covid-19 itu viral di media sosial pekan lalu. Dalam video itu, Sehan mengumpat kanan-kiri karena ada keputusan menteri yang mempersulit upayanya menyalurkan bantuan untuk warganya yang paling membutuhkan. ${ }^{21}$ Tidak hanya di Bolaang Mongondow Timur, Sulawesi Utara, cerita suram tentang kekacauan penyaluran bantuan juga terjadi di banyak tempat di Indonesia. Di Pekanbaru, Riau, kepala rukun warga ramai-ramai menolak bantuan karena data warga yang mereka usulkan dipangkas tanpa alasan jelas. Sebaliknya, di Bogor, Jawa Barat menginginkan bantuan secara tunai. Beragam insiden itu bermuara pada kacaunya sistem pendataan warga yang jatuh miskin akibat wabah corona. Kebijakan pemerintah selain memanusiakan manusia (dimensi humanisasi) juga wajib membebaskan manusia dari dominasi struktural, yang membuat manusia terjerat dalam pemerasan dan kemiskinan.

Kebijakan penanganan Covid-19 selain memperhatikan aspek humanisasi, juga harus mendudukan orang pada keadaan yang sama tanpa adanya diskriminasi, terlebih lagi bagi masyarakat yang terdampak secara langsug akibat adanya penyebaran virus corona. Menurut Hart, bahwa salah satu central element dalam membicarakan keadilan adalah adagium "treat like cases alike and different cases differently" 22 Hart mengemukakan alasan yang mendasari kenapa memperlakukan "setiap kedaan yang sama diperlakukan serupa dan

21 https://kolom.tempo.co/read/1338378/kisruh-bantuan-covid-19/full\&view=ok. Diakses tanggal 7 Mei 2020.

${ }^{22}$ H. LA. Hart. 1972.The Concept of Law, Clarendon Press, Oxford University Press, Oxford, hlm. 159. 
memperlakukannya berbeda jika memang memiliki sebabs ebab yang berbeda pula" tersebut sebagai berikut:

"This is so because any set of human beings will resemble each other in some respects and differ from each other in others and, until it is established what resemblance and differences are relevant." ${ }^{23}$

Pemenuhan atas kebutuhan dasar bagi masyarakat menjadi tanggungjawab Pemerintah dan Pemerintah Daerah, hal ini sejalan dengan ketentuan Pasal 6 Undang - Undang Nomor 6 Tahun 2018 tentang Kekarantinaan Kesehatan (UU No 6 Tahun 2018). Dalam ketentuan pasal tersebut ditegaskan "Pemerintah Pusat dan Pemerintah Daerah bertanggung jawab terhadap ketersediaan sumber daya yang diperlukan dalam penyelenggaraan Kekarantinaan Kesehatan”.

Sebagaimana telah diuraikan pada subbab sebelumnya bahwa saat kita tengah berada dalam situasi darurat kesehatan sebagaimana yang telah diumumkan oleh presiden sehingga pemberlakuka kebijakan dalam penanganan covid-19 mengacu pada ketentuan didalam UU No 8 Tahun 2018. Jika kita membaca secara komprehensif subtansi uu tersebut juga diamanatkan dalam masa kekarantinaan kesehatan setiap orang mempunyai hak memperoleh perlakuan yang sama, hal ini ditegaskan dalam ketentuan Pasal 7 UU No 6 Tahun 2018.

Spirit UU No 6 Tahun 2018 sebenarnya telah mengandung konsep humanisasi dalam penormaanya akan tetapi spirit tersebut untuk dikatakan berhasil atau sesuai dengan tujuanya haruslah diuji dengan fakta empirik. Fakta empiriklah yang akan membuktikan bahwa norma tersebut berjalan sesuai dengan tujuannya atau tidak. Dari fakta yang ada tergambar bahwa penanganan covid-19 dilakukan dalam berbagai aspek mulai dari aspek ekonomi, sosial, hukum dan beberapa aspek lainnya yang bersentuhan langsung dengan masyarakat. Saat ini kebijakan pemerintah yang sangat bersentuhan langsung dengan masyarakat mengenai pembagian sembako, bantuan langsung tunai (BLT), keringanan pembayaran kredit sampai dengan subsidi listrik. Penanganan yang diserahkan kepada masing - masing daerah membuat kebijakan menjadi beragam dan tidak seragam, daerah yang memiliki pendapatan daerah tinggi tentu akan memberikan bantuan yang cukup maksimal sebaliknya daerah yang pendapat daerahnya terbilang cukup atau bahkan sedikit tentu akan mengalami sedikit kesulitan dalam memberikan bantuan kepada masyarakat. Saat ini pemerintah telah melakukan banyak hal dalam penanganan Covid-19, namun kebijakan yang diambil jika tidak tepat pada sasaran dan merata tentu akan menimbulkan diskriminasi bagi masyarakat.

Pemberian bantuan yang tumpang tindih akibat data yang tidak akurat juga merupakan problematika yang mendasar, simak saja penyampaian menteri keuangan Sri Mulyani Indrawati yang menyatakan adanya kemungkinan tumpang tindih data dalam penyaluran bantuan sosial atau bansos selama masa pandemi virus Corona atau Covid-19 karena data terpadu Kementerian Sosial belum dimutakhirkan dengan kondisi setelah adanya Covid-19. Sehingga,

${ }^{23} \mathrm{Ibid}$. 
penerima bantuan belum mencerminkan kondisi terakhir. Berdasarkan data terpadu kesejahteraan sosial, Sri Mulyani mengatakan penerima PKH mencapai 10 juta orang, Kartu Sembako 20 juta KPM, stimulus listrik 450 VA 24 juta rumah tangga, stimulus listrik $900 \mathrm{VA}$ 7,2 juta rumah tangga, BLT dana desa 11 juta KPM, kartu prakerja 5,6 juta KPM. ${ }^{24}$

Tumpang tindih bantuan yang diberikan pemerintah akan mengakibatkan adanya warga masyarakat yang tidak mendapatkan bantuan sama sekali dan ada masyarakat yang telah mendapatkan bantuan lebih dari sekali. Tentu hal ini akan sangat merugikan masyarakat karena ada perlakuan yang tidak adil dalam pendistribusian bantuan pemerintah. Kebijakan pemerintah haruslah berbasis pada kebaikan yang menurutnya baik baginya juga harus diberlakukan bagi yang lain begitupun demikian kebijakan yang dipandang tidak pantas diberlakukan baginya juga tidak boleh dilakukan terhadap orang lain. Pemerintah sebagai pemegang otoritas kebijakan dalam penanganan Covid-19 ideal dapat mengukur kadar kemaslahatan suatu kebijakan ketika diberlakukan kepada masyarakat.

Pada prinsipnya sumber pemenuhan kebutuhan dasar bagi masyarakat yang terdampak secara langsung penyebaran pandemi virus corona terbagi menjadi tiga sumber yang terdiri dari sumber bantuan sosial nasional yang dipelopori oleh Pemerintah Pusat, bantuan sosial daerah yang diserahkan oleh Pemerintah Daerah Provinsi dan Kabupaten/Kota serta sumber bantuan sosial dari dana desa yang diserahkan oleh Pemerintah Desa. Bantuan sosial Pemerintah Pusat meliputi : bantuan sosial tunai (BST), pembebasan biaya listrik, kartu prakerja, program keluarga harapan, dan kartu sembako.

Data penerima bantuan sosial yang masih tumpang tindih serta pemberian bantuan yang dilakukan secara bersamaan dari tiga sumber yang berbeda (Pemerintah, Pemerintah Daerah dan Pemerintah Desa) membuat proses penyaluran bantuan kepada masyarakat menjadi tidak tepat sasaran dan efisien. Sehingga banyak penerima bantuan yang mendapatkan bantuan lebih dari sumber yang berbeda namun terdapat pula penerima bantuan yang sama sekali tidak mendapatkan bantuan dari tiga sumber yang ada. Olehnya itu, proses pemberian bantuan baiknya dilakukan secara bertahap dimulai dari pemerintah Pusat sampai kepada Pemerintah Desa. Proses pembagian bantuan sosial atau pemenuhan hak dasar warga masyarakat yang dilakukan secara bertahap tergambar sebagaimana ragaan dibawah ini :

\begin{tabular}{|c|c|c|}
\hline Waktu & Sumber bantuan & Sasaran \\
\hline $\begin{array}{c}\text { Bulan Pertama - Bulan } \\
\text { Kedua }\end{array}$ & Pemerintah Pusat & $\begin{array}{c}\text { Warga Masyarakat Se } \\
\text { Indonesia berdasarkan } \\
\text { data Kemensos }\end{array}$ \\
\hline $\begin{array}{c}\text { Bulan Ketiga - Bulan Ke } \\
\text { empat }\end{array}$ & Pemerintah Daerah Provinsi & $\begin{array}{c}\text { Warga Masyarakat Se } \\
\text { Provinsi berdasarkan data } \\
\text { Dinsos Provinsi }\end{array}$ \\
\hline $\begin{array}{c}\text { Bulan kelima - Bulan Ke } \\
\text { enam }\end{array}$ & Pemerintah Daerah & Warga Masyarakat Se \\
Kabupaten/Kota & Kabupaten/Kota \\
\hline
\end{tabular}

\footnotetext{
${ }^{24}$ https://bisnis.tempo.co/read/1340277/tumpang-tindih-data-bansos-sri-mulyani-lebih-baikdaripada. Diakses tanggal 10 Mei 2020
} 


\begin{tabular}{|c|c|c|}
\hline & & $\begin{array}{c}\text { berdasarkan data Dinsos } \\
\text { Kabupaten/Kota }\end{array}$ \\
\hline $\begin{array}{c}\text { Bulan ketujuh - Bulan } \\
\text { Kedelapan }\end{array}$ & Pemerintah Desa & $\begin{array}{c}\text { Warga Masyarakat Desa } \\
\text { berdasakan data di Kantor } \\
\text { Desa }\end{array}$ \\
\hline
\end{tabular}

Ragaan diatas mengambarkan proses pembagian bantuan kebutuhan dasar masyarakat menjadi tidak tumpang tindih karena dilakukan secara bertahap mulai dari pusat sampai tingkat desa. proses pembagian bantuan dengan menggukan skema secara bertahap dari sumber yang berbeda juga dapat memberikan jaminan kepastian kepada masyarakat bahwa dalam rentang waktu yang terbilang cukup, pemerintah dapat menyediakan bantuan secara bertahap bagi keberlangsungan hidup dan kehidupan masyarakat ditengah penyebaran Covid-19. Dengan kebijakan yang dilakukan secara bertahap sebagaimana ragaan diatas akan mendatangkan kemaslahatan bagi setiap warga negara. Maslahah dapat juga dikatakan sebagai suatu tindakan atau pelaksanaan suatu urusan yang menghasilkan kebaikan atau sesuatu untuk kebaikan. ${ }^{25}$ Tindakan yang mengedepankan maslahah bagi setiap masyarakat merupakan ciri dari nilai - nilai jabariyah yang menitiktekankan pada iktiar setiap pemangku kebijakan untuk memberikan kebijakan yang baik kepada setiap warga negara.

Sebagaimana yang telah dipahami bahwa konsep berfikir humanisasi yakni untuk merealisasikan kemaslahatan manusia, yaitu untuk meraih kemanfaatan, sekaligus untuk menolak timbulnya kemudaratan, juga untuk melepaskan diri dari beraneka ragam kesulitan. Kebijakan pemenuhan kebutuhan dasar bagi setiap warga masyarakat agar bernilai baik serta memberikan nilai kemanusiaan, maka sistem pendataan bagi setiap warga yang berhak mendapatkan bantuan sosial harus dilakukan secara mutahir oleh kementrian sosial. Kemudian proses penyaluran bantuan sosial idealnya dilakukan secara bertahap dari pusat sampai ketingkat desa. kembali pada konsep dasar humanisasi yang dimaknai dimaknai sebagai proses memanusiakan manusia, menghormati dan mengangkat derajat manusian sebagaimana difitrahkan oleh sang pencipta. Maka standar - stadar pemberian bantuan sosial harus memiliki nilai - nilai yang mengangkat fitrah manusia.

\section{Landasan Hukum Kebijakan Penanganan Covid-19: Telaah Perspektif Liberasi}

Tanggal 2 maret 2020 menjadi tanggal yang bersejarah bagi Indonesia, pada saat itu menjadi hari pertama penanda Indonesia juga menjadi salah satu negara yang masuk dalam jajaran tersebar virus corona. Tanggal itu juga menjadi titik awal perumusan kebijakan pemerintah dalam penanganan covid-19. Terlepas dari isu - isu yang menyatakan bahwa jauh sebelum tanggal tersebut negara kita telah mengalami penyebaran virus corona namun satu hal yang pasti ialah kini kita tengah berperang melawan pandemik yang menjadi musuh bersama dihamoir seluruh belahan dunia. Melawan musuh yang terlihat mungkin jauh lebih muda

${ }^{25}$ Muhammad Khalid Mas'ud, 1995, Filsafat Hukum Islam dan Perubahan Sosial, Alih Bahasa: Yudian W. Asmin, Surabaya: al Ikhlas, hlm. 153. 
dibanding dengan musuh yang tak nampak oleh indera penglihat, pun demikian adanya merumuskan kebijakan melawan musuh yang tak nampak juga harus lebih matang dan komprehensif.

Seiring perjalananya pemerintah telah melakukan beberapa kebijkan dalam penanganan penyebaran covid-19, varian kebijakan tersebut dimaksudkan untuk menekan angka penyebaran virus di Indonesia. Dilihat dari aspek bentuk Kebijakan yang diambil pemerintah dapat dibagi atas dua bentuk yakni berupa instrumen himbauan dan pembentukan hukum. Himbauan sebagai langkah pertama yang ditempuh pemerintah sejak virus corona mulai masuk wilayah Indonesia, kebijakan berupa himbauan ini berbagai macam diantaranya ialah himbauan untuk melakukan pembatasan jarak (social distancing), pembatasan fisik (physical distancing) hingga himbauan yang menyangkut penundaan pembayaran dan penagihan kredit bagi masyarakat menengah kebawah. Varian kebijakan berupa himbauan yang dipilih pemerintah nampaknya tidak berjalan seirama dengan kehendak pemerintah, hal tersebut terkonfirmasi dengan masih banyaknya aktifitas masyarakat yang jauh dari kata pembatasan jarak ataupun pembatasan fisik. Himbauan tersebut kembali terkonfirmasi tidak efektif takkala banyak badan hukum baik perbankan maupun non perbankan yang juga tidak melakukan penundaan kredit masyarakat. Meskipun data terbaru perbankan telah melakukan kebijakan penundaan kredit namun tidak untuk semua debitur melainkan hanya bagi debitur yang terdampak langsung virus corona. ${ }^{26}$

Kembali pada himbauan pembatasan jarak (social distancing) maupun pembatasan fisik (physical distancing) yang terbilang masih belum efektif dalam penerapannya. Dilihat dari prespektif teori legal sistem yang dipopulerkan oleh seorang pakar ilmu hukum bernama Lawrence M. Friedman ketidakefektifan himbauan tersebut dapat menyangkut 3 (tiga) hal yakni struktur hukum (legal structure), substansi/materi hukum (legal substance), dan budaya hukum (legal culture $^{27}$. Pandangan Friedman diatas memiliki kemiripan dengan Kees Schuit, menurutnya sistem hukum terdiri dari tiga unsur yang memiliki kemandirian tertentu yang saling berkaitan yakni unsur idiil, unsur oprasional dan unsur aktual $^{28}$. Kemudian dari prespektif hukum positif, kedudukan himbauan berada pada titik yang paling rendah kekuatan hukumnya. Himbauan belum berada pada level perintah yang memuat sanksi hukum dalam susbtansinya sebagaimana kekuatan norma hukum yang berbentuk undang - undang atau sejenisnya.

Kemudian dari aspek kebijakan dalam bentuk hukum, pemerintah telah mengeluarkan Perpu No 1 Tahun 2020 dan Keputusan Presiden Nomor 12 Tahun 2020 tentang Penetapan Bencana Nonalam Penyebaran Corona Virus Disease

\footnotetext{
${ }^{26} \mathrm{https}$ ///www.cnnindonesia.com/ekonomi/20200417131608-78-494505/keringanancicilan-kredit-cuma-untuk-debitur-terdampak-corona. Diakses tanggal 3 Mei 2020

27 Achmad Ali , 2005, Keterpurukan Hukum di Indonesia Penyebab dan Solusinya, Bogor: Ghalia Indonesia, hlm. 1.

${ }^{28}$ J.J.H. Bruggink, 1996, Refleksi Tentang Hukum, terjemahan B. Arief Sidharta, Bandung : Citra Aditya Bakti, hlm. 162. Lihat Juga : Shidarta, 2013, Hukum Penalaran dan Penalaran Hukum, Yogyakarta : Genta Publishing, hlm. 144. Lihat juga : Rocky Marbun, 2014, “Grand Design Polik Hukum Pidana dan Sistem Hukum Pidana Indonesia Berdasarkan Pancasila dan Undang-Undang Dasar Negara Republik Indonesia 1945”, Padjadjaran Jurnal Ilmu Hukum, Volume 1 - No 3 -, hlm. 561.
} 
2019 (Covid-19) sebagai bencana nasional (Kepres No 12 Tahun 2020). Perpu No 1 Tahun 2020 secara subtansi mengatur berkaitan dengan kebijakan keuangan negara dalam penanganan covid-19. Perpu yang terdiri dari 5 (lima) bab tersebut dijadikan sebagai legalitas bagi pemerintah dalam mengatur pengelolaan keuangan negara pada masa pandemi berlangsung. Kehadiran Perpu No 1 Tahun 2020 laksana kapal yang akan berlayar menuju samudera, layar belum terkembang dengan baik ombakpun telah datang menghampiri untuk menguji eksistensi pelayaran. Tak lama setelah kehadiran Perpu No 1 Tahun 2020 gelombang pengujian (yudicial review) ke Mahkamah Konstitusi (MK) datang silih berganti mulai dari masyarakat sampai dengan organisai masyarakat (Ormas).

Gelombang pengujian terhadap Perpu No 1 Tahun 2020 dilakukan karena dipandang terdapat pasal yang berpotensi merugikan hak konstitusional warga negara, kemudian disamping itupula membuka ruang adanya kekebalan hukum bagi pejabat dalam penanganan pandemi Covid-19. Hal tersebut tampak pada rumusan Pasal 27 ayat (2) yang mengatur "Anggota KSSK, Sekretaris KSSK, anggota sekretariat KSSK, dan pejabat atau pegawai Kementerian Keuangan, Bank Indonesia, Otoritas Jasa Keuangan, serta Lembaga Penjamin Simpanan, dan pejabat lainnya, yang berkaitan dengan pelaksanaan Peraturan Pemerintah Pengganti Undang-Undang ini, tidak dapat dituntut baik secara perdata maupun pidana jika dalam melaksanakan tugas didasarkan pada iktikad baik dan sesuai dengan ketentuan peraturan perundang-undangan. Rumusan pasal ini menjadi salah satu sorotan oleh kalangan masyarakat dalam pengujian di Mahkamah Konstitusi, sebab dinilai tidak mengambarkan nilai keadilan bagi masyarakat.

Idealnya pembentukan hukum harus tunduk pada asas - asas dalam pembentukannya sehingga membuat hukum dapat berjalan sesuai dengan kebutuhan masyarakat. Pembentukan aturan hukum yang baik menurut Lon Luvois Fuller setidaknya memenuhi 8 (delapan) asas yang dinamakan principles of legality, yaitu:

1. A failler to achieve rules at all, so that every issue must be decided on an ad hoc basis.

2. A failure to publicize, or at least to make available to the affected party, the rules he is expected to observe.

3. The abuse of retroactive legislation, which not only can not itself guide action, but under cuts the integrity of rules prospective in effect, since it puts them under the threat of retrospective change.

4. A failure to make rules understandable.

5. The enactment of contradictory rules.

6. Rules that require conduct beyond the powers of the affected party.

7. Introducing such frequent changes in the rules that the subject cannot orient his action by them.

8. A failure of congruence between the rules as announced and their actual administration. ${ }^{29}$

${ }^{29}$ Lon Luvois Fuller, 1975, The Morality of Law, Yale University Press, hlm. 39. 
Suatu aturan hukum yang baik apabila memenuhi delapan kriteria, yaitu berlaku secara umum, diumumkan, tidak berlaku surut, disusun dalam rumusan yang dapat dimengerti, tidak saling bertentangan, dapat dilakukan secara wajar, tidak mudah berubah, ada kesesuaian antara aturan dan pelaksanaannya. Melihat kebijakan hukum yang dikeluarkan oleh pemerintah dalam penanganan covid-19 dapat disebut belum memenuhi kriteria asas sebagaimana disebutkan diatas, akbiat dari pembentukan hukum yang tidak sejalan dengan asas pembentukan hukum atau tidak memiliki nilai keadilan sebagai nilai yang dituju pastilah akan menimbulkan problematika dalam penerapannya. Persamaan kedudukan dihadapan hukum (equality before the law) sebagai prinsip negara hukum haruslah dijunjung tinggi serta mengandung makna tidak ada yang memiliki kekebalan hukum dalam setiap pengambilan kebijakan terlebih lagi dalam keadaan darurat kesehatan. Asas persamaan dihadapan hukum merupakan asas dimana terdapatnya suatu kesetaraan dalam hukum pada setiap individu tanpa ada suatu pengecualian. ${ }^{30}$ Asas equality before the law bergerak dalam payung hukum yang berlaku umum (general) dan tunggal. Ketunggalan hukum itu menjadi satu wajah utuh di antara dimensi sosial serta fenomena yang terjadi dimasyarakat. ${ }^{31}$

Sejalan dengan pilar kedua dalam hukum profetik, spirit liberasi dalam konteks hukum memiliki makna, bahwa setiap kebijakan yang dikeluarkan tidak dalam kerangka membatasi kebebasan manusia, melainkan usaha untuk menjamin keberlangsungan eksistensial manusia. Liberasi juga dapat difahami sebagai spirit hukum dalam menjamin agar setiap orang terhindar dari potensi kesewenangwenangan pihak lain yang berpotensi menciderai eksistensinya. Dalam konteks perlindungan hukum bagi rakyat, maka suatu hukum yang bermoral adalah hukum yang mampu menjamin keberadaannya dari kesewenang-wenangan penguasa. Untuk itu maka dalam konteks berhukum ditetapkan satu kerangka prosedural yang mampu menjembatani terbentuknya hukum yang bersandar pada nilai-nilai agama. spirit liberasi adalah spirit pembebasan, yakni membebaskan manusia dari belenggu dan hegemoni manusia lainnya. Liberasi adalah upaya untuk menetralisir segala bentuk tindak laku yang dehumanistik atau anti-kemanusiaan. Jadi liberasi dapat dipahami sebagai tindakan yang tidak mendiskriminasi setiap manusia atau dengan kata lain mendudukan setiap manusia seseuai dengan fitrahnya. Konsep ini oleh hukum positif disebut pula sebagai aturan yang mendudukan setiap orang sama dimata hukum.

Landasan hukum yang digunakan oleh pemerintah dalam pengelolaan keuangan negara dalam stabilitas untuk penanganan pandemi Covid-19 memiliki peluang yang sangat besar untuk terjadinya tindakan penyalagunaan wewenang, hal tersebut memungkinkan terjadi karena adanya perlindungan hukum (tidak dapat dituntut baik pidana maupun perdata) bagi pemerintah apabila terjadi kesalahan dalam bertindak.

30 Julita Melissa Walukow, 2013, "Perwujudan Prinsip Equality Before The Law Bagi Narapidana Di Dalam Lembaga Pemasyarakatan Di Indonesia", Lex et Societatis, Vol.I/No.1/Jan-Mrt, hlm. 164

${ }^{31}$ ibid 


\section{Menakar Dimensi Nilai Transendental dalam Kebijakan Covid-19}

Setiap kebijakan dalam penanganan Covid-19 baik yang berdimensi humanisasi maupun liberasi berakhir pada satu titik yang sama yakni transendensi. Transendensi merupakan pilar ketiga dan yang utama dalam konsep berfikir profetik, semua kebijakan didasarkan dan ditujuhkan untuk menjalankan perintah sang pencipta. Keberadaan transendensi merupakan dasar dari etos kebijakan yang humanis (amar ma'ruf) dan liberatif (nahi mungkar) dimana titik orientasinya ialah terjaganya martabat manusia, terjaminnya kesejahteraan masyarakat dan terbangunya tatanan hukum yang beradab. Transendensi adalah definisi teoritis dari Yu'minuna billah yang diterjemahkan secara operasional menjadi membawa manusia menuju Tuhannya. Para penganjur ilmu-ilmu Profetik menekankan posisi penting transendensi setelah humanisme dan liberasi. Transendensi hendak menjadikan nilai-nilai transendental (keimanan) sebagai bagian penting dari proses membangun peradaban. ${ }^{32}$

Transendensi adalah upaya mengarahkan tujuan hidup manusia agar bisa hidup secara bermakna. Nilai-nilai transendental ini adalah nilai-nilai ketuhanan sebagaimana diajarkan di dalam Islam. Nilai-nilai ketuhanan ini yang mengarahkan manusia untuk menemukan nilai-nilai luhur kemanusiaan; atau dengan perkataan lain mengajak manusia menjalankan nilai-nilai kemanusiaan itu menuju ke nilai-nilai ketuhanan. ${ }^{33}$

Nilai transenden menjadi dasar setiap kebijakan yang diambil oleh pemerintah dalam menjalankan roda pemerintahan terlebih lagi pada masa penyebaran virus corona seperti saat ini. Nilai transenden pada prinsipnya telah ada dalam butir Pancasila dan telah terjabaran dalam pembukaan maupun batang tubuh UUD NRI Tahun 1945. Oleh karena telah ia telah terjabarkan dan menjadi roh didalam menjalankan pemerintahan maka setiap kebijakan pemerintah wajib untuk sejalan dengan spirit nilai nilai transenden.

Kebijakan Pemenuhan kebutuhan dasar serta landasan hukum yang digunakan bagi masyarakat ditengah pandemi idealnya menarik nilai - nilai transendental. Pemerintah merupakan penjawentahan dari nilai spiritual yang kemudian dijabarkan dalam bentuk tindakan. Layak sifat nabi yang pada konteks saat itu memiliki funsi sebagai kepala pemerintahan sekaligus pemimpin mempunyai ciri sebagai manusia yang ideal secara spiritual-individual, tetapi juga menjadi pelopor perubahan, membimbing masyarakat ke arah perbaikan dan melakukan perjuangan tanpa henti melawan penindasan. ${ }^{34}$

Sebagai iktibar dalam sejarah, Nabi Ibrahim melawan Raja Namrud, Nabi Musa melawan Fir'aun, Nabi Muhammad yang membimbing kaum miskin dan budak belia melawan setiap penindasan dan ketidakadilan, mempunyai tujuan untuk menuju kearah pembebasan. ${ }^{35}$ Menurut Ali Syari'ati dalam Hilmy para nabi

${ }^{32}$ Irwanto, 2014, "Pendekatan Ilmu Sosial Profetik Dalam Memahami Makna Ayat-Ayat Al-Qur'an", LITERASI, Volume. V, No. 1 Juni, hlm. 6.

${ }^{33}$ Shidarta. Loc.Cit.

${ }^{34}$ Muhammad Basyam Rusydi Az-Zain, 2007, Sekolah Para Nabi 1 \& 2, Yogyakarta: Pustaka Marwa, tanpa halaman.

${ }^{35}$ Nur Hanafi. Loc. Cit. hlm. 3. 
tidak hanya mengajarkan dzikir dan do'a tetapi mereka juga datang dengan suatu ideologi pembebasan. ${ }^{36}$

Konteks saat ini pemerintah secara unsur merupakan pemimpin sekaligus juga pelopor perubahan bagi masyarakat kea rah yang lebih baik melalui kebijakan yang diambil, terlebeih lagi kebijakan tersebut dilakukan pada masa Covid-19, namun melihat gambaran yang telah diuaraikan pada subbab sebelumnya nampak kebijakan yang dikeluarkan oleh pemerintah baik dari sisi landasan hukum maupun pemenuhan kebutuhan masyarakat masih sangat jauh dari nilai transendental.

\section{KESIMPULAN}

Penyebaran virus corona (Covid-19) di Indonesia terus bertambah diberbagai daerah sehingga membuat segala lini aktifitas masyarakat merasakan dampak secara langsung. Kebutuhan dasar masyarakat menjadi hal yang sangat terdampak dengan adanya penyebaran virus ini, berbagai kebijakan telah dilakukan oleh pemerintah dan pemerintah daerah untuk mengatasi kebutuhan masyarakat yang secara lansgung maupun tidak langsung terdampak virus corona. Dari kebijakan yang diambil oleh pemerintah sampai dengan saat ini penulis menyimpulkan beberapa hal diantaranya : Pertama, pemenuhan kebutuhan dasar masyarakat (bantuan sosial) masih belum tepat sasaran dikarenakan data penerima bantuan yang tidak akurat. Kedua, proses penyaluran bantuan untuk pemenuhan kebutuhan dasar masyarakat terjadi tumpang tindih dikrenakan penyaluran bantuan tidak dilakukan bertahap yang dimulai dari Pemerintah Pusat sampai kepada Pemerintah Desa, melainkan dilakukan secara bersamaan sehingga tidak terjadi efisiensi dan pemenuhan kebutuahn secara bertahap. Ketiga, landasan hukum dalam pengelolaan keuangan penanganan pandemi Covid-19 berpeluang terjadi penyalagunaan wewenang karena terdapat perlindungan hukum berupa tidak dapat dituntut baik secara perdata maupun pidana apabila terjadi kesalahan dalam penggunaan anggran dimasa pandemi.

\section{SARAN}

Kebijakan penanganan Covid-19 akan dapat menyentuh nilai humanisai, liberasi dan transendental jika kebijakan tersebut memberikan nilah maslahah kepada setiap warga masyarakat yang terdampak secara langsung maupun tidak terhadap penyebaran Covid-19. Beranjak dari tebaran pemikiran serta kesimpulan yang tergambar diatas, maka penulis merekomendasikan beberapa hal yakni, pendataan peneriman bantuan sosial harus dilakukan secara akuran dan mutahir, proses penyaluran bantuan terhadap kebutuhan masyarakat idealnya dilakukan secara bertahan dari Pemerintah Pusat sampai kepada Pemerintah Desa, landasan hukum pengelolaan keungan penaganan Covid-19 harus dilakukan perubahan untuk menghilangkan ketentuan kekebalan hukum dalam pengaturanya demi mewujudkan prinsip keadilan dan kesamaan dihadapan hukum.

${ }^{36}$ Ali Shari'ati, 1996, Humanisme: Antara Islam dan Mazhab Barat, terj. Husein Anis alHabshi, Bandung: Pustaka Indah, hlm. 119. 


\section{DAFTAR PUSTAKA}

\section{A. Buku}

Absori dkk, 2015, Paradigma Hukum Profetik; kritik terhadap asumsi asumsi dasar Ilmu Hukum Non-Sistematik, Jogja: Genta Publishing.

Absori et al, 2018, Pemikiran Hukum Profetik Ragam Paradigma Menuju Hukum Berketuhanan, Yogyakarta ; Ruas Media.

Ali, Achmad, 2005, Keterpurukan Hukum di Indonesia Penyebab dan Solusinya, Bogor: Ghalia Indonesia.

Basyam Rusydi Az-Zain, Muhammad, 2007, Sekolah Para Nabi 1 \& 2, Yogyakarta: Pustaka Marwa.

Bruggink, J.J.H, 1996, Refleksi Tentang Hukum, terjemahan B. Arief Sidharta, Bandung : Citra Aditya Bakti.

Fuller, Lon Luvois, 1975, The Morality of Law, Yale University Press.

Hart, H. LA, 1972.The Concept of Law, Clarendon Press, Oxford University Press, Oxford

Kuntowijoyo, 1997, Identitas Politik Umat Islam, Bandung: Mizan.

----------, 1998, Paradigma Islam: Interpretasi untuk Aksi, Cet.VIII, AE. Priyono (ed), Bandung: Mizan,

Marzuki, Peter Mahmud, 2005, Penelitian Hukum : Edisi Revisi. Jakarta : Kencana.

Shari'ati , Ali, 1996, Humanisme: Antara Islam dan Mazhab Barat, terj. Husein Anis al- Habshi, Bandung: Pustaka Indah

Shidarta, 2013, Hukum Penalaran dan Penalaran Hukum, Yogyakarta : Genta Publishing.

\section{B. Jurnal/Makalah/Koran}

Briando, Bobby, Sulistyo Purnomo, Agung, 2019, "Etika Profetik Bagi Pengelola Keuangan Negara, Jurnal Akuntansi Multiparadigma, Volume 10, Nomor 2, Agustus.

Hanafi, Nur, "Konseptualisasi Profetik", Jurnal al Hikmah, 5(1), 1-8.

Irwanto, 2014, "Pendekatan Ilmu Sosial Profetik Dalam Memahami Makna AyatAyat Al-Qur'an", LITERASI, Volume. V, No. 1 Juni

Marbun, Rocky, 2014, "Grand Design Polik Hukum Pidana dan Sistem Hukum Pidana Indonesia Berdasarkan Pancasila dan Undang-Undang Dasar Negara Republik Indonesia 1945”, Padjadjaran Jurnal Ilmu Hukum, Volume 1 - No 3.

Melissa Walukow, Julita, 2013, "Perwujudan Prinsip Equality Before The Law Bagi Narapidana Di Dalam Lembaga Pemasyarakatan Di Indonesia”, Lex et Societatis, Vol.I/No.1/Jan-Mrt.

Rusfi, Mohammad, 2014, "Validitas Maslahat Al-Mursalah Sebagai Sumber Hukum”. AL-'ADALAH Vol. XII, No. 1 Juni,

Alkostar, Artidjo, "Peluang dan Tantangan Hukum Profetik Bagi Pengembangan Hukum Nasional Di Era Digital”, Makalah tidak dipublikasikan, tanpa tahun. 
Supriyadi dan Ivan Yudharta, "Maslahah Dibalik Penundaan Pilkada : Pemikiran yang dilandaskan pada kajian Hukum Profetik", Mercusuar, 31 Maret 2020 Supriyadi, "Maslahah dibalik Penundaan Pilkada", Kareba Sulteng. 4 April 2020

\section{Internet}

Shidarta, "hukum profetik: antara humanisasi, liberasi, dan transenden", https://busineslaw.binus.ac.id/2019/05/02/antara_humanisasi_liberasi_trans endensi/. Diakses pada tanggal 1 Mei 2020.

CNN Indonesia, “ keringanan cicilan debitur terdampak corona" https://www.cnnindonesia.com/ekonomi/20200417131608-78

494505/keringanan-cicilan-kredit-cuma-untuk-debitur-terdampak-corona.

Diakses tanggal 3 Mei 2020.

Tempo, “Kisruh Bantuan Covid19”,https://kolom.tempo.co/read/1338378/kisruhbantuan-covid-19/full\&view=ok. Diakses tanggal 7 Mei 2020.

Koran Tempo, "Tumpang Tindih Data Bansos" https://bisnis.tempo.co/read/1340277/tumpang-tindih-data-bansos-srimulyani-lebih-baik-daripada. Diakses tanggal 10 Mei 2020.

\section{Peraturan Perundang-Undangan}

Undang - Undang Nomor 6 Tahun 2018 Tentang Kekarantinaan Kesehatan Lembaran Negara Republik Indonesia Tahun 2018 Nomor 128. Tambahan Lembaran Negara Republik Indonesia Nomor 6236.

Peraturan Pemerintah Pengganti Undang - Undang Nomor 1 Tahun 2020 Tentang Kebijakan Keuangan Negara Dan Stabilitas Sistem Keuangan Untuk Penanganan Pandemi Corona Wrus D/Sease 2019 (Covtd- 19) Dan/Atau Dalam Rangka Menghadapi Ancaman Yang Membahayakan Perekonomian Nasional Dan/Atau Stabilitas Sistem Keuangan. Lembaran Negara Republik Indonesia Tahun 2020 Nomor 87. Tambahan Lembaran Negara Republik Indonesia Nomor 6485. 